„Bohemistyka” 2021, nr 2, ISSN 1642-9893

Magdalena BRODACKA

DOI: $10.14746 /$ bo.2021.2.4

Uniwersytet Jagielloński

Instytut Nauk o Człowieku w Wiedniu

\section{Agon, los a może fatum? Milana Kundery zmagania z Europą Środkową ${ }^{1}$}

Keywords: Milan Kundera, Central Europe, Central European identity, Central European novel, communism, political transformation

Slowa kluczowe: Milan Kundera, Europa Środkowa, tożsamość środkowoeuropejska, powieść środkowoeuropejska, komunizm, transformacja ustrojowa

\section{Abstract}

The aim of the paper is to reconstruct the Central European idea in Milan Kundera's work. The study analyses key works for the Central European category: The Book of Laughter and Forgetting and The Stolen West or The Tragedy of Central Europe. This text is an attempt to create the Kundera's dictionary of Central Europe, and therefore it addresses such categories as fate and fate, memory and forgetfulness, scapegoat theory and the metaphorical death of the novel. The article highlights the key role of culture as a matter of Central European identity in opposition to the dominant historical-political discourse.

Celem artykułu jest rekonstrukcja idei środkowoeuropejskiej w twórczości Milana Kundery. Analizie zostaja poddane kluczowe dla tej kategorii utwory: Ksiega śmiechu i zapomnienia oraz Zachód porwany albo tragedia Europy Środkowej. Tekst ten stanowi próbę utworzenia Kunderowskiego słownika Europy Środkowej, dlatego poruszone zostają takie kategorie jak: los i fatum, pamięć i zapomnienie, teoria kozła ofiarnego oraz metaforyczna śmierć powieści. W artykule zostaje podkreślona kluczowa rola kultury, jako budulca tożsamości środkowoeuropejskiej w opozycji do dominującego dyskursu historyczno-politycznego.

${ }^{1}$ Tekst powstał w ramach stypendium Józef Tischner Junior Visitting Fellowship w Instytucie Nauk o Człowieku w Wiedniu [Institute for Human Sciences in Vienna].
„Rzeczywistość znamy jedynie w czasie przeszłym. Nie znamy jej takiej, jaka jest w chwili teraźniejszej, w chwili, w której się wydarza, w której jest. A chwila teraźniejsza nie jest podobna do wspomnienia o niej" (Kundera 2015a, s. 145) - przywołuję tę wypowiedź Milana Kundery, ponieważ uznaję ją za fundamentalną dla próby rozumienia czeskiej narracji tożsamościowotwórczej w drugiej połowie XX wieku. Stosunek Kundery do rzeczywistości - różny, jak się wydaje, od kontemplacyjnego modelu Miłosza - naznacza i ukierunkowuje nie tylko prozę tego wybitnego, czesko-francuskiego pisarza, ale również liczne dyskusje o charakterze społeczno-politycznym, które toczyły się na łamach czeskich czasopism emigracyjnych i krajowych od lat sześćdziesiątych ubiegłego wieku. Wypowiedź autora Zdradzonych testamentów pochodzi z eseju $W$ poszukiwaniu utraconej teraźniejszości, w którym Kundera dowodzi, że utracie owej wymykającej się teraźniejszości ma przeciwstawiać się powieść. Nie trudno skonstatować, że to właśnie powieściowy model Kundery spełnia cel postawiony przez jego wielkich poprzedników, przede wszystkim zaś przez Prousta, którego dzieło stoi w centrum Kunderowskich inspiracji. Rzeczywistość każdego człowieka, zawsze „spóźniona” w stosunku do jej racjonalnej recepcji, fascynowała pisarza zwłaszcza w kontekście jej moralnej interpretacji dokonywanej przez osoby postronne. Interpretację taką autor Nieznośnej lekkości bytu określa mianem kiczotwórczej,

[...] jest [ona] zniewoleniem pochodzacym ze zbiorowej podświadomości; podszeptem metafizycznego suflera; trwałym wymogiem społecznym; siłą. [...] Zarzuca woal komunałów na chwilę teraźniejszą, aby zniknęła twarz rzeczywistości. Po to, byś nigdy nie wiedział, co przeżyłeś (Kundera 2015a, s. 165-166).

Cały projekt powieściowy Kundery, tak ochoczo przez niego komentowany w licznych esejach i wywiadach, opiera się w gruncie rzeczy na jednym z pozoru kontrowersyjnym założeniu, a mianowicie powieść zawiesza osąd moralny (Kundera 2015a, s. 12). Autor Żartu tworzy wyobrażoną przestrzeń, w której postaci pozbawione są obowiązku odgrywania określonych typów, prezentowania rozmaitych ideologii, pozwalają sobie na niewiedzę i nierozumienie doświadcza- 
nej rzeczywistości, która stawia przed nimi wyzwania, jakim często nie potrafią sprostać. W niepewności i wieloznaczności każdego ,ja” tkwi mądrość powieści.

W tym szeroko zakrojonym projekcie fenomenologicznym Kundera mierzy się z licznymi sprzecznościami wytwarzanymi na styku dziejów ludzkości i historii powieści. Pisarz jest oczywiście rzecznikiem tej drugiej, choć doskonale wie, że to właśnie ta pierwsza niejednokrotnie warunkuje problematykę jego dzieł. Granica tych dwóch rodzajów historii przebiega wewnątrz samych powieści i oddziela problemy oddalone od siebie nie o kilometry lecz o milimetr. Problematyka owej przepuszczalnej, nieszczelnej granicy komplikuje odbiór dzieł Milana Kundery - fluktuacje, które zachodzą pomiędzy narratorem, bohaterami i samym autorem oraz tym co wyobrażone i tym co rzeczywiste, odzierają twórczość czeskiego pisarza z poczucia pewności i niejednoznaczności zarówno co do świata powieściowego, jak i samej postawy twórcy. Stąd już tylko krok do relatywizmu lub zupełnego odrzucenia pełnego sprzeczności świata powieści Kundery. Świata, który jednocześnie drażni i fascynuje, wywołując wciąż żywe dyskusje, ciągłe oskarżenia względem samego autora, po potrzebny - co postaram się udowodnić - powrót do jego myśli. „Czym jest jednostka? Gdzie przebywa jej tożsamość? Odpowiedzi na te pytania poszukują wszystkie powieści” (Kundera 2015a, s. 15) - zwłaszcza może Księga śmiechu i zapomnienia, pisana przez Kunderę już na emigracji we Francji w latach siedemdziesiątych, po opublikowaniu której pisarz został pozbawiony obywatelstwa czechosłowackiego ${ }^{2}$. To w niej najpełniej objawia się wspomniane przeze mnie rozróżnienie na historię rzeczywistości i historię powieści, to w niej również pisarz doskonale obrazuje problematykę Girardowskiego trójkąta ofiary

\footnotetext{
${ }^{2}$ Ksiega śmiechu i zapomnienia wyszła po raz pierwszy w 1979 roku we francu-
} skim przekładzie, w języku czeskim ukazała się dopiero w 1981 nakładem emigracyjnego wydawnictwa „Sixty-Eight Publishers” w Toronto. Po raz drugi w języku czeskim, a po raz pierwszy w Czechach powieść została wydana dopiero w 2017 roku w wydawnictwie „Atlantis”. Zyskała nagrodę Książki Roku Lidových novin 2017. i przemocy, którego schemat powieli w najbardziej znanym manifeście środkowoeuropejskości - Zachodzie porwanym albo tragedii Europy Środkowej.

Kunderę uznaję za twórcę środkowoeuropejskiej mapy wyobrażonej drugiej połowy XX wieku oraz powieściowego słownika, który ową mapę opisuje i dookreśla. Na Księge śmiechu $i$ zapomnienia składają się trzy wymiary przestrzenne: Praga okresu normalizacji po stłumieniu Praskiej Wiosny w 1968 roku, prowincjonalne miasteczko bez nazwy na Zachodzie Europy (prawdopodobnie we Francji) oraz wyspa dzieci, która istnieje jedynie w wyobraźni bohaterów bądź pośmiertnych zaświatach. Do pierwszej przestrzeni przynależy Mirek inteligent wyrzucony za swoje poglądy z pracy na uniwersytecie, który pragnie odzyskać listy z przeszłości łączące go z komunistyczną aktywistką Zdeną. Przestrzeń anonimowego miasteczka zamieszkuje Tamina - główna bohaterka powieści, mimo że nie pojawia się w każdej z siedmiu znacząco różniących się oraz niepowiązanych ze sobą części. Taminę uznać można za przeciwieństwo Mirka - kobieta wraz z mężem (który niedługo później umiera) decyduje się na emigrację i ucieka z Czechosłowacji. Także ona pragnie odzyskać wspomnienia pozostawione w ojczyźnie - dzienniki ze wspólnego życia z mężem, którego rysy twarzy zostały stopniowo zamazane przez mijający czas. To właśnie postać Taminy uznaje się za prefigurację losu samego Kundery. Zachodni czytelnicy i krytycy Księgi śmiechu i zapomnienia sygnalizowali trudności w rozumieniu tematyki i przesłania dzieła przypominającego raczej zbiór esejów niż zaplanowaną uprzednio całość. Poza historia Mirka i Taminy Kundera prezentuje liczne sceny seksu, które nie tyle obrazują erotyczną fiksację samego narratora, co wskazują na erozję relacji międzyludzkich i symptomatyczny brak miłości. O tym, że pisarz wyraża tęsknotę za uczuciami indywidualnymi, niewystawionymi na spojrzenia innych ludzi, świadczy część szósta powieści o charakterze autobiograficznym, w której Kundera opowiada o afazji ojca i jego powolnym odchodzeniu. Lustrzanym odbiciem tej sceny jest śmierć Taminy na wyspie dzieci poprzedzona utratą życiodajnych wspomnień. 
Temu krótkiemu opisowi quasi-fabuły przyświecają dwa cele: po pierwsze, pragnę pokazać, że połączenie fikcji z autentycznymi wydarzeniami z historii Czechosłowacji oraz elementami autobiografii zapewniło Kunderze międzynarodowe zainteresowanie i zagraniczny sukces, który - wbrew temu, co twierdzili niektórzy rodacy pisarza nie był uwarunkowany celowym uproszczeniem języka i tematyki powieści, bowiem Księga śmiechu i zapomnienia do dziś stanowi wyzwanie dla wszystkich kunderologów. Po drugie zaś - co najważniejsze - poszczególne części powieści skupione są wokół tematów, słów-kluczy: tytułowego zapomnienia, które dokonuje się na dwóch planach - historycznym i indywidualnym; śmiechu będącego wyrazem ambiwalencji wpisanej w życie, jak i kiczu charakterystycznego dla zbiorowych zachowań; wreszcie losu jako metafory agonu między dziejowością a jednostką ${ }^{3}$. Wszystkie one natomiast mogą należycie wybrzmieć właśnie w powieści, która, zdaniem Kundery, w XX znajdowała się w centrum kultury Europy Środkowej:

Mówię o powieści europejskiej nie tylko po to, by odróżnić ją od powieści (na przykład) chińskiej, lecz aby powiedzieć również, że jej historia jest $\mathrm{p}$ o $\mathrm{n}$ a d $\mathrm{n}$ a ro d o w a [podkr. - M.B.]; że powieść francuska, powieść angielska czy powieść węgierska nie są zdolne stworzyć własnej, niezależnej historii, lecz, że wszystkie one uczestniczą we wspólnej, ponadnarodowej historii, która stworzyła jedyny kontekst, w jakim może się objawić sens rozwoju powieści i wartość poszczególnych dzieł. Podczas różnych faz powieści inicjatywę przejmowały, niczym w biegu sztafetowym, różne narody [...] wiek XX i jego środkowoeuropejska przygoda wraz z Kafką, Musilem, Brochem i Gombrowiczem... (Kundera 2015a, s. 35-36)

W wypowiedzi tej odnaleźć można również znamienny dla Kundery ton świadomego wykraczania poza granice swojego języka ojczystego, a zatem podawanie w wątpliwość istnienia czystego idiomu narodowego literatury czeskiej. W interesującym artykule, który w la-

3 „I ta właśnie rzecz (abstrakcyjna rzecz nazywana przeze mnie tematem) nadaje całej powieści wewnętrzną spójność, najmniej może widoczną, ale najważniejszą. Księdze śmiechu i zapomnienia nadaje ją wyłącznie jedność kilku różnych tematów (i motywów). Czy jest to powieść? Tak, tak sądzę. Powieść jest medytacja nad egzystencją dzięki pośrednictwu wyobraźniowych postaci” (Kundera 2015b, s. 98). tach dziewięćdziesiątych ukazał się na łamach „Cross Currents” pisarz uzasadniał, że istnieją trzy kluczowe dla badań literaturoznawczych konteksty: narodowy, światowy i środkowoeuropejski. Ten ostatni jest splotem dwóch pierwszych, a uchwycenie jego sedna stanowi nieustanne wyzwanie związane $\mathrm{z}$ : niejasnymi, zmiennymi i dyskusyjnymi granicami geograficznymi Europy Środkowej; z policentrycznością punktów odniesienia, które znacząco zmieniają perspektywę środkowoeuropejską (inaczej jawi się ona w Warszawie, Budapeszcie, Wiedniu czy Lublanie); z ciągłym podważaniem przez wielu komentatorów potrzeby istnienia takiego konceptu myślowego jak Europa Środkowa: „Jednak trudności w definiowaniu czy zbadaniu określonego fenomenu nie stanowią dowodu na to, że ów fenomen nie istnieje" Kundera 1993, s. 12). Według pisarza naturalne środowisko środkowoeuropejskie jest pewna niezbywalną oczywistością: to w nim wybrzmiewa imperatyw ponadnarodowy i polilingwistyczny.

Taka postawa jest poniekąd echem ideologii postnacjonalistycznej głoszonej przez awangardę w latach dwudziestych ubiegłego wieku. Nie pozostaje to bez znaczenia dla powieści Kundery, który do fabuły Księgi śmiechu i zapomnienia zaprasza samego Paula Éluarda - guru ówczesnych czeskich awangardystów, który razem z André Bretonem przyjechał do Pragi w 1935 roku. Wprowadzenie autentycznych wydarzeń historycznych na karty powieści sprawia, że historia kraju w środku Europy staje się bohaterką Księgi śmiechu i zapomnienia. Historia ta przyobleka się w losy kilkorga bohaterów, między innymi w Vladimíra Clementisa, który przed II wojną światową był adwokatem, dyplomatą i awangardowym pisarzem, a po 1948 roku został ministrem spraw zagranicznych w komunistycznym rządzie Klementa Gottwalda. Jak podaje Marci Shore,

Wkrótce jednak on i trzynastu innych komunistów zostało aresztowanych przez własnych towarzyszy, a następnie osądzonych jako trockiści, syjoniści, titoiści, burżuazyjni nacjonaliści, zdrajcy, szpiedzy, sabotażyści, wrogowie ludu czechosłowackiego i wrogowie socjalizmu. W więzieniu byli torturowani przez śledczych. Oskarżeni wygłaszali opracowane wcześniej, samobiczujące przyznania się do winy. Clementis znalazł się wśród jedenastu, których powieszono (Shore 2012a, s. 33). 
Clementisa skazano na śmierć w słynnym procesie Rudolfa Slánskiego, ale to nie jedyne nawiązanie do komunistycznych procesów pokazowych i egzekucji ${ }^{4}$, które Kundera opisuje w swojej powieści. Drugi proces, z 1949 roku wymierzony był w Záviša Kalandrę, marksistowskiego krytyka literackiego, awangardzistę, komunistę, przyjaciela przywołanego już Éluarda. Powieszono go w 1950 roku razem z grupą Milady Horákovej ${ }^{5}$. Przyglądał się temu jego partyjny kolega, nieświadomy podobnego losu, Vladimír Clementis ${ }^{6}$.

Los Clementisa Kundera przywołuje w scenie otwierającej powieść i za pomoca swoistej ekfrazy odtwarza zdjęcie upamiętniające inauguracyjne orędzie Gottwalda do narodu. Na głowie tego ostatnie-

${ }^{4}$ Rudolf Slánský był czeskim działaczem komunistycznych pochodzenia żydowskiego. W latach 1945-1951 sprawował funkcję sekretarza generalnego Komunistycznej Partii Czechosłowacji, później zastąpiony przez Klementa Gottwalda. W listopadzie 1952 roku, po oskarżeniu o działalność antynarodową i szpiegostwo na rzecz Izraela, został skazany na śmierć przez powieszenie. Zrehabilitowany przez sąd w 1963 roku. Jak podaje Marci Shore w latach 1948-1952 w Czechosłowacji przeprowadzono szereg procesów politycznych, podczas których za pomocą tortur wymuszano przyznania się do winy. Bezprawnie uwięziono wówczas 35000 osób, wydano 223 wyroki śmierci i zamordowano 178 oskarżonych. Ponadto 22000 obywateli przebywało bezprawnie w przymusowych obozach pracy.

${ }^{5}$ Milada Horáková była czeską działaczką polityczną zaangażowaną w działalność demokratyczną i feministyczną. W czasie II wojny światowej uczestniczyła w antyfaszystowskim ruchu oporu, była więziona i torturowana w obozie koncentracyjnym w Terezinie. Wraz z Kalandra i wieloma innymi osobami Horákową aresztowano po przewrocie lutowym w 1948 roku i oskarżono o: „spisek trockistowski na rzecz amerykańskiego imperializmu; o przygotowanie tajnego planu zniszczeni czechosłowackiej demokracji ludowej, przywrócenia kapitalistycznego wyzysku i wywołania trzeciej wojny światowej”. Ostatecznie została zrehabilitowana dopiero w 1990 roku (Shore 2012b, s. 103). Fragmenty stenogramu z procesu można znaleźć w książce Marci Shore (Shore 2012b).

${ }^{6}$ Więcej o narodzinach czechosłowackiej awangardy, jej związków z komunizmem oraz z awangardą francuską i rosyjską pisze Marci Shore w książce Nowoczesność jako źródlo cierpień, zwłaszcza zaś w rozdziałach: Skoro jesteśmy dumn z Freuda Romans rodzinny "Żydokomuny " oraz Inżynieria w wieku niewinności genealogia dyskursu wewnątrz Zwiazku Pisarzy Czechosłowackich, 1949-1967. go można zauważyć futrzaną czapkę, którą chwilę wcześniej troskliwy Clementis zdjął i założył swojemu przywódcy. Cztery lata po dokonaniu egzekucji Clementisa postanowiono skazać na nieistnienie również w pamięci zbiorowej, toteż ze wszystkich zdjęć usunięto jego postać. Nie usunięto natomiast futrzanej czapki ochraniającej wodza przez mrozem i śniegiem. Los Kalandry natomiast Kundera przywołuje w ustępie autobiograficznym, posługując się wymowną metafora tańca o nazwie ,koło”. Dziewiętnastoletni wówczas pisarz nie kryje przy tym swojej przynależności do partii i autentycznej radości z wygranych przez komunistów wyborów ${ }^{7}$. Pierwsze wykluczenie Kundery z partii zbiegło się w czasie z powieszeniem Závišy Kalandry i Milady Horákovej w Pradze w 1950 roku.

Jak oderwany meteoryt ja też wyleciałem z koła i lecę do dziś. Są ludzie, którym dane jest umrzeć pośród krążenia i tacy, którzy rozbijają się, padając. Ci drudzy (do których ja należę) odczuwają stale cichutka tęsknotę do zagubionego tańca w kole, bo przecież każdy z nas jest obywatelem wszechświata, w którym wszystko krąży po okręgach. [...] A młodzi Czesi tańczyli, wiedząc, że wczoraj w tym mieście huśtała się na sznurze pewna kobieta i pewien surrealista; tańczyli tym bardziej zapamiętale, bo ten taniec był manifestacją ich niewinności, czystości, która jaskrawo odbijała się od czarnych przewinień tych dwojga wisielców, którzy zdradzili naród i jego ideały. [...] Lecz z trwogą w sercu wiedziałem, że oni lecą jak ptaki, a ja spadam jak kamień, że oni mają skrzydła, mnie zaś na zawsze skrzydeł pozbawiono (Kundera 2013, s. 95-98).

${ }^{7}$ Milan Kundera wstąpił do Czechosłowackiej Partii Komunistycznej w 1948 roku, jednak dwa lata później został z niej wyrzucony. Skutki wykluczenia można dostrzec w jego debiutanckiej powieści Żart. Los, który spotkał Ludwika w pewnym stopniu odzwierciedlał historie młodego Kundery. W 1949 roku pisarz dostał list, w którym jego przyjaciel Jaroslav Dewtter krytykował wysoko postawionego urzędnika partyjnego. Kundera odpowiedział na ów list w podobnym tonie. Obaj ponieśli kare - Dewtter został wyrzucony z partii i z uniwersytetu, natomiast Kunderę wykluczono jedynie $\mathrm{z}$ partii, pozwolono mu kontynuować studia na FAMU (Wydział Filmowy i Telewizyjny Akademii Sztuk Scenicznych w Pradze), gdzie rozpoczął swoją karierę akademicką. Do partii przyjęto go ponownie w roku 1956, a w 1970 ostatecznie usunięto w wyniku czystek, które nastały po zdławieniu Praskiej Wiosny. 
O tym, że przynależność do partii komunistycznej była dla Kundery nie tylko doświadczeniem formacyjnym, ale i bezalternatywnym niech świadczy fakt, że mimo naocznie doświadczanych zbrodni dokonywanych na jego znajomych po piórze, sześć lat później pisarz powrócił do partyjnego ,koła”, o czym w późniejszych ustępach autobiograficznych już nigdy nie wspomnial ${ }^{8}$. Na kartach Księgi śmiechu $i$ zapomnienia rozliczył natomiast internacjonalizm awangardy i to, co leżało u jej podstaw: przekraczanie kolejnych granic do momentu, aż nie było dokąd pójść i w czym się zakorzenić: „Istniała tylko czysta przygodność, która była wielkim nieszczęściem, czymś nie do zniesienia. Toteż w świecie czystej przygodności imperatywem egzystencjalnym było dokonywanie wyboru, podjęcie jakichś zdecydowanych działań" (Shore 2012b, s. 203). Kundera portretuje Éluarda jako zapamiętanego w tańcu komunistę, który mimo próśb nie zrobił nic, aby ocalić od śmierci swojego przyjaciela Kalandrę. Metafora tańca w okręgu, do którego - po odłączeniu - nie można już nigdy więcej wrócić, obrazuje nie tylko „tańczący” konformizm Kundery (Judt, Snyder 2019, s. 268), ale i koncepcję zapętlonego czasu, opartego na powtarzalności i konieczności historycznej.

Tą oddziałującą na wyobraźnię sceną pisarz zapowiada problematykę całej powieści - co czeka człowieka, gdy historia dziejów oddzieli się od jego rzeczywistości i nie będzie już jego losem, lecz nieznośnym fatum? Problematyka losu jest moim zdaniem jedną z naj-

${ }^{8}$ Zakłamywanie historii - albo raczej przemilczenie pewnych jej aspektów znalazło się w centrum krytyki wymierzanej w Kunderę, zwłaszcza po jego emigracji do Francji. Jacek Baluch tak komentował ten problem: „W kwestii historii na przykład wielu Czechów - jak sądzę - ma do Kundery pretensje, że występując w imieniu pamięci historii, pełnego świadectwa tej pamięci nie daje. W jego powieści tak ważne wydarzenia jak rok 1968 pojawiają się jakby na marginesie. Jeśli ktoś nie wie, kim był Záviš Kalandra, to nie bardzo zrozumie wzmiankę o jego powieszeniu, nie mówiąc już o tym, że można się zastanawiać, dlaczego z tego największego procesu politycznego po roku 1948, którego główną bohaterką była Milada Horákova, wybiera Kundera jednego z dwóch sadzonych w nim przedstawicieli komunistycznej lewicy, do procesu tego poniekąd sztucznie dołączonych". Zob. Kundera. Materiaty... 1988, s. 47. bardziej kluczowych w dyskusji nad filozofią powieściową i polityczną Milana Kundery. Pojęcia, które wypracowuje on na kartach swoich powieści są często dookreślane albo wręcz poprzedzane licznymi wypowiedziami pisarza na łamach czasopism i podczas dyskusji toczonych na zjazdach Związku Pisarzy Czechosłowackich. „Przychodzi chwila, kiedy obraz naszego życia odłącza się od tego życia, staje się niezależny i z wolna zaczyna roztaczać nad nami swoje panowanie" (Kundera 2015b, s. 157) - tak Kundera zdefiniował pojęcie losu w swoim słowniku Sześćdziesięciu pięciu słów kluczowych w interpretacji jego dzieł. Zanim jednak ów słownik, jako część Sztuki powieści, został wydany w 1986 roku, pisarz zgoła inaczej rozpatrywał kwestię losu. O wadze tego słowa jako swoistej metafory oddzielenia jednostki od rzeczywistości niech świadczy fakt, że jedną z podstawowych i ciągle płodnych definicji Europy Środkowej jest określenie jej za pomocą losu właśnie.

\section{Europa Środkowa - los czy fatum?}

Historia pojęcia losu w słowniku Kundery jest dość długa, jednak nie można jej w pełni zrozumieć bez jednej z kluczowych dyskusji między nim a Václavem Havlem na łamach czasopism „Listy”, „dnešek”, „Tváŕ” oraz „Host do domu” z lat 1968-1969. Jednak już w roku poprzedzającym słynną wymianę poglądów, trzydziestoośmioletni i uznawany Kundera wygłosił przemówienie inaugurujące IV Zjazd Związku Pisarzy Czechosłowackich w Pradze (IV. Sjezd Svazu československých spisovatelů, 1968). Był on wówczas członkiem partii komunistycznej i rzecznikiem jej postępowych przemian określanych „socjalizmem z ludzką twarzą”. Warto jednak pamiętać, że pisarz należał do pokolenia stalinistów, dla których zdrada w Monachium w 1938 roku była wydarzeniem formującym niechęć do tak zwanego Zachodu, a którzy w latach sześćdziesiątych uwierzyli w bezkrwawą destalinizację. Kundera wyjaśniał zgromadzonym pisarzom, że mądrość partii objawia się w tym, że nie chce ona oceniać wartości dzieł, ponieważ jest to zadanie należące do krytyków literackich. Według 
niego złota wolność literatury czeskiej rozpoczęła się wraz z rokiem 1948, a czechosłowaccy pisarze są zobligowani, by z tej wolności korzystać. Jak w praktyce ten postulat miałby się ziścić? Twórcy ponownie - niczym XIX-wieczni budziciele czeskiej tożsamości - powinni zainteresować się losem swojego narodu, pytać o jego wyjątkową tożsamość i rolę, którą miałby spełnić na nowej mapie Europy: „W XIX wieku nasz naród był na peryferiach historii świata. Natomiast teraz znajduje się w samym jej środku" (Kundera 1968a, s. 29). Jednocześnie autor Żartu przypomina, że istnienie narodu czeskiego nigdy nie było oczywiste i pewne, dlatego „Není nic důležitějšího, než aby si životní význam své kultury a svého písemnictví plně uvědomovalo celé naše národní společenství" (Kundera 1968a, s. 25). Wyraźne odwołania Kundery do okresu odrodzenia narodowego, pracy nad językiem oraz kształtowania idiomu literackiego łączyły się z postulatem misyjności literatury jako sztuki zaangażowanej społecznie. Debaty podczas IV Zjazdu utrzymane zostały w tonie zapoczątkowanym cztery lata wcześniej, kiedy pisarze zgodzili się co to tego, że przyszedł czas przezwyciężenia kultu jednostki i dogmatyzmu. Były to próby rozliczenia się $\mathrm{z}$ przeszłością (zwłaszcza $\mathrm{z}$ procesami wewnątrzpartyjnymi i egzekucjami) oraz związanym z nimi kryzysem sumienia. Warto zaznaczyć, że w 1967 ukazał się Żart, czyli jedna z najważniejszych i najlepszych powieści Kundery, w której dokonał on przejścia $\mathrm{z}$ tak zwanego dyskursu samokrytyki, na poziom relacji jednostki z sumieniem i dokonywanymi przez nią wyborami zakłócanymi nieprzewidywalnością historii. W świetle problematyki tej przełomowej powieści (która krążyła jako rękopis przed IV Zjazdem), w dyskusjach zgromadzonych pisarzy wybrzmiały głośno nowe deklaracje - podstawą tworzenia jest wolność jednostki, zatem twórca nie może być sojusznikiem ideowym partii ani inżynierem ludzkich dusz'.

${ }^{9}$ Więcej o zmieniającym się dyskursie czterech Zjazdów Pisarzy Czechosłowackich w latach 1949-1967 pisze Marci Shore w książce Nowoczesność jako źródto cierpień, zwłaszcza w rozdziale Inżynieria wieku niewinności: genealogia dyskursu wewnątrz Związu Pisarzy Czechostowackich, 1949-1967 (Shore 2012a).
W tym samym tonie utrzymany został esej Kundery Český úděl (Czeski los, 1968) zapoczątkowujący kontrowersyjną dyskusję intelektualistów zaangażowanych w przemiany społeczne określane mianem Praskiej Wiosny. Już sam tytuł wskazuje na pewną kontynuację poczynionych wcześniej rozpoznań oraz wpisuje się w sięgającą XIX wieku debatę na temat czeskiej kwestii (česká otázka), która stanowi tytuł książki pierwszego prezydenta niepodległej Czechosłowacji Tomáša Garrigue'a Masaryka (Masaryk 1969). W związku z tym, że problem ten został już wnikliwie opisany zarówno przez czeskich jak i polskich badaczy, na potrzeby tego tekstu przywołam jedynie te tezy, które stanowią trzon dla rozważań Kundery ${ }^{10}$. Jak słusznie wskazuje Adam F. Kola

Najbardziej znana czeska debata dotyczyła sensu czeskich dziejów. Rozpoczęła się ponad sto lat temu i pobudza czeskie życie intelektualne do dziś. [...] Dyskusja obejmuje także zagadnienia związane z Europa Środkową, jej miejscem w Europie, zwłaszcza między Europą Zachodnia i Wschodnią, oraz usytuowaniem Czech (Czechosłowacji) w tej Europie (Kola 2011, s. 285).

U podstaw debaty nad sensem czeskich dziejów stały sformułowane przez XIX-wiecznego pisarza i myśliciela Huberta Gordona Schauera pytania o sens istnienia narodu czeskiego, który został w znacz-

\footnotetext{
${ }^{10}$ Za początek debaty nad sensem czeskich dziejów uznaje się artykuł Huberta Gordona Schauera „Naše dvě otázky” z 1886 roku. Autor pytał, jakie zadania stoją przed narodem czeskim i w jaki sposób Czesi usprawiedliwiaja swoje istnienie na mapie Europy. Problem ten podjał następnie Tomasz Garrigue Masaryk w publikacji Česká otázka z 1895 roku. Prezydent Czechosłowacji postawił tezę, że czeski ruch narodowotwórczy opiera się na idei humanizmu i dziedzictwie reformacji zapoczątkowanej przez Husytów. Kwestia czeska może stać się kwestia światową jedynie w kategoriach filozoficznych i etycznych. Z tezą tą polemizował historyk Josef Pekař zarzucając Masarykowi, że ten nie opiera się na wiedzy historycznej, podważył również znaczenie rewolucji husyckiej, a ciagłości narodu czeskiego upatrywał w sztuce baroku. Więcej o ideowych różnicach między stanowiskiem Masaryka i Pekařa znaleźć można w książce Adama F. Koli Europa w dyskursie polskim, czeskim i chorwackim. Rekonfiguracje krytyczne. O tym, jak żywotna była česká otázka przekonuje natomiast Božena Komárková w swoim eseju Ceská otázka tehdy a dnes (Czeskie pytanie - kiedyś i dziś, „Svědectvî” 1985, nr 76).
} 
nej mierze zgermanizowany i strukturalnie podległy Monarchii (zob. Schauer 1917). Pytaniom tym towarzyszy nieustanne wybieganie w przyszłość - tylko horyzont czasu przyszłego nadaje sens działaniom emancypacyjnym i tożsamościowotwórczym. I to właśnie owego horyzontu możliwości esej Kundery zdaje się być pozbawiony. W Czeskim losie pisarz przyznaje się do znużenia nieustannie pojawiającym się w czeskiej kulturze pytaniem o sens dziejów, a zatem niepodległości małego narodu w Środku Europy. Momentem przełomowym tak rozumianej historiozofii był dla Kundery sierpień 1968 roku, kiedy to Czesi - jako jedyny naród - pokazali światu swą ,,pewność, rozum i jedność" (Kundera 1968b). Tym razem obywatele tego małego kraju w środku Europy zdali egzamin z pytania o sens własnego istnienia, udowodnili, że są myślącymi krytycznie racjonalistami, którzy demistyfikują wszelkie iluzje i utopie - oto pochwała obywateli za zaangażowanie w demokratyczne przemiany w obrębie modelu marksistowskiego socjalizmu.

Jednak to nie tezy z tekstu Kundery interesują mnie najbardziej istotne jest to, czego pisarz nie formułuje wprost, a co sprawia, że los warunkowany biegiem dziejów przekształca się w fatum. Myślenie w kategoriach losu i przeznaczenia umożliwia zaistnienie i zakorzenienie w zbiorowej wyobraźni takiego pojęcia jak konieczność historyczna. Koniecznością historyczną komuniści usprawiedliwiali swoje zbrodnie, czystki w partii, brak dobrobytu i społeczną apatię. Niebezpieczeństwo płynące z utraty perspektywy przyszłości od razu zauważył i celnie wypunktował Václav Havel w polemicznym tekście Český úděl? (Czeski los?) z 1969 roku. Nieustanne zwracanie się w przeszłość grozi zaniedbaniem rzeczywistości tu i teraz. Jego zdaniem przeszłość nie wymaga działania i podejmowania ryzykownych decyzji, a więc niejako zdejmuje ciężar odpowiedzialności. Zaniedbanie i niedocenienie teraźniejszości umożliwia uleganie złudzeniom, a te nie mają nic wspólnego z postulowaną przez Kunderę krytycyzmem.

Całkiem logicznym elementem tego pseudokrytycznego iluzjonizmu robiącego wszystko, co tylko możliwe, aby uwolnić nas od odpowiedzialności za bieg wydarzeń i stać się ich autentyczną częścią, jest i Kunderowska koncepcja „,zeskiego losu”. Nie wierze w tego rodzaju fatum i myśle, że przede wszystkim to my sami jesteśmy kowalami własnego losu i nie zwolni nas z tego ani egoistyczna wymówka, ani położenie geograficzne, ani odwołanie się do naszej stuletniej tradycji losu balansującego między suwerennością a podporządkowaniem. To przecież nic innego jak myślenie abstrakcjami, które zacierają naszą konkretną odpowiedzialność za konkretne czyny (Havel 1969).

Na rzecz argumentów Havla miał świadczyć fakt, że w momencie pisania polemiki (czyli w lutym 1969 roku) większość postulatów Praskiej Wiosny nie została spełniona, co zdaniem dramaturga dowodziło, że Kundera żył w zakłamaniu. Kilka lat później, w słynnym eseju Siła bezsilnych Havel nazwie takie postepowanie samototalizmem i upatrywać w nim będzie największego niebezpieczeństwa zagrażajacego kondycji ludzkości (zob. Havel 2011). Kundera nie pozostawił argumentów Havla bez odpowiedzi. W swojej replice Radikalismus a exhibicionismus (Radykalizm i ekshibicjonizm, 1969) ponownie zdefiniował pojęcie losu: „Los jest tym, co zostało nam dane. Człowiek jest śmiertelny, a Czechy leżą w Europie Środkowej. Czeska polityka musi więc opierać się na znajomości czeskiego losu i na możliwościach w nim zawartych" (Kundera 1969). Kundera zarzuca Havlowi niebezpieczny brak nadziei i to, co jego oponent nazywa lokalna iluzją (socjalizm demokratyczny), dla niego jest koniecznością, którą należy rozpatrywać w perspektywie centralnej, czyli europejskiej, a nie jedynie lokalnej.

Na tym polemika musiała się zakończyć, ponieważ czasopisma, na łamach których się toczyła, zostały zlikwidowane,

[...] Milan Kundera stracił pracę i znalazł się na indeksie, Václav Havel natomiast też znalazł się na indeksie i podjął pracę... w browarze. Później Kundera udał się na emigrację, a Havel... do więzienia. Historia nie po raz pierwszy dopisała w ten sposób ironiczny komentarz [...] (Jagodziński 1988, s. 25).

Ale nie o ironiczny komentarz historii chodzi, jak uważa Andrzej Jagodziński - choć należy przyznać, że Havel był bliższy przewidzenia realnego scenariusza - lecz o argumenty obu twórców, które wydaja się być zaskakująco podobne. To, co Kundera nazywa losem, Havel określa mianem fatum; Kunderowskie myślenie w kategoriach ko- 
nieczności historycznej i zwracanie się w przeszłość, autor Garden party kontruje koniecznością wprowadzenia „normalności”, która panuje w większości cywilizowanych krajów; tam, gdzie jeden dostrzega powtarzalność historii, drugi usilnie dąży do jej zwieńczenia, czyli nastania demokracji. Choć drogi życiowe i decyzje polityczne Kundery i Havla zasadniczo się różniły, to sposób ujmowania przez nich problemów zdominowany był przez te same kategorie zapoczątkowane w dyskursie towarzyszącym odrodzeniu narodowemu. Było to położenie geograficzne i związana z nim kolonizacja Czech, kultura na usługach wartości nacjonalistycznych, nieustanne poczucie zagrożenia i misja wyzwalania się.

Mając w pamięci powyższe rozważania o dziejowości kultury czeskiej, powróćmy raz jeszcze do definicji losu, którą Kundera zweryfikował, przebywając na emigracji. Narrator Ksiegi śmiechu i zapomnienia tak opisuje Mirka śledzonego przez urzędników tajnej policji StB:

Był zakochany w swoim losie i wydawało mu się, że nawet jego marsz ku zagładzie jest wzniosły i piękny. Proszę mnie dobrze zrozumieć, nie powiedziałem, że był zakochany w samym sobie, tylko - że w swoim losie. A to dwie absolutnie różne rzeczy. Jego życie jak gdyby usamodzielniło się i nagle miało swe całkowicie własne interesy, niepokrywające się z interesami Mirka. Nazywam to przemianą życia w los. Los ani myślał kiwnać palcem dla Mirka (dla jego szczęścia, bezpieczeństwa, dobrego samopoczucia i zdrowia), za to Mirek był gotów zrobić wszystko dla swego losu (żeby był wielki, jasny, piękny, żeby miał styl i zrozumiały sens). Czuje się odpowiedzialny za swój los, jego los zaś nie czuje się odpowiedzialny za niego (Kundera 2013, s. 18).

Kundera celowo personifikuje los, który zamiast opatrzności przypomina raczej niepokorne dziecko wymagajace czułości i zrozumienia. W latach siedemdziesiątych, kiedy już mało kto naprawdę wierzył w komunizm, rozpatrywanie Kunderowskiego losu poszerzyło się o wymiar humorystyczny, który „nie jest śmiechem, kpiną, satyrą, lecz szczególnym rodzajem komizmu, o którym Paz powiada (i jest to klucz do zrozumienia humoru), że »wszystko, czego się tyka, czyni dwuznacznym«" (Kundera 2015a, s. 10). Niemal identycznie powieściopisarz definiuje ironię -
Ironia drażni. Nie dlatego, że drwi i napastuje, lecz dlatego, że pozbawia nas pewności, odsłaniając niejednoznaczność świata (Kundera 2015b, s. 150-151).

To, co Kundera w swoich powieściach eksploruje, a czego w żaden sposób nie był w stanie uchwycić w formie politycznego eseju, sprowadza się w gruncie rzeczy do ulubionego powiedzenia pisarza:

Człowiek myśli, Bóg się śmieje. [...] Dlaczego jednak na widok myślącego człowieka Bóg się śmieje? Ponieważ człowiek myśli, a prawda mu się wymyka. Ponieważ im więcej ludzie myślą, tym bardziej ich myśli uciekają od siebie. I dlatego wreszcie, że człowiek nie jest nigdy tym, kim myśli, że jest (Kundera 2015b, s. 182-183).

Ostatnie zdanie trafnie oddaje przemiane, która zaszła w pisarzu los bowiem postanowił się od niego oddzielić, zyskał twarz ,normalizacji” - terroru lat siedemdziesiątych i objął cenzurą wszystko, co było dla Kundery najważniejsze - jego powieści.

\subsection{Chichot historii, czyli czlowiek we mgle}

„Tyrania przeszłości nigdy nie pozwoliłaby nam pogodzić się ze światem, zwłaszcza, gdy w grę wchodzi zawarcie pokoju z byłymi wrogami politycznymi i ciemiężcami” (Donskis 2012, s. 34) - komentarz Leonidasa Donskisa do Ksiegi śmiechu i zapomnienia chyba najtrafniej oddaje pewne napięcie, które Kundera sukcesywnie budował w powieści. Napięcie to litewski filozof łączył z immanentną cechą nowoczesności, która z jednej strony oparta jest na imperatywie zapamiętywania - kolekcjonowania wspomnień i myślenia generacyjnego, a z drugiej wymaga wybiórczego zapomnienia niezbędnego do życia we wspólnocie - poczynajac od rodziny, na społeczeństwie i narodzie skończywszy. Filozof ostrzega przed skrajnościami: fiksacyjne rozpamiętywanie prowadzi do tyranii pamięci nad rzeczywistością, natomiast skrajna ignorancja i odrzucenie przeszłości buduje świat barbarzyński. „Pamięć staje się narzędziem małych i słabych, a zapominanie najlepiej służy interesom dużych i potężnych" (Donskis 2012, s. 38) - nie trudno zauważyć, że owa antynomia jest wpisana w powieść Kundery, ale przyjmuje ona postać nie zbiorowego, lecz zu- 
pełnie jednostkowego doświadczenia. Autor Księgi śmiechu i zapomnienia bierze w nawias dominującą rolę historii i traktuje ją jak dekorację sceniczną dla akcji swoich powieści. Taki zabieg Shore określa mianem redukcji fenomenologicznej: pisarz ,zawiesza swoje przekonanie o istnieniu świata, naszej wiedzy o tym, co nastąpiło później” (Shore 2012a, s. 224). Sprzyja to doświadczeniu Zeitgeist przez powieściowych bohaterów, czyli elementarnemu połączeniu z rzeczywistością, w której okoliczność historyczna wytwarza nową sytuację egzystencjalną dla Kunderowskich postaci.

Podobnie rzecz się ma z „praska wiosną, której nie opisuję w Księdze śmiechu $i$ zapomnienia $\mathrm{w}$ jej wymiarze polityczno-historyczno-społecznym, ale jako jedną z podstawowych sytuacji egzystencjalnych: człowiek (pokolenie ludzi) działa (dokonuje rewolucji), lecz czyn jego wymyka mu się, przestaje być mu posłuszny (rewolucja szaleje, morduje, niszczy); człowiek robi wszystko, by odzyskać i poskromić nieposłuszny czyn (pokolenie zakłada ruch opozycyjny, reformatorski), lecz na próżno. Nigdy nie zdołamy odzyskać czynu, który raz nam się wymknął (Kundera 2015b, s. 49).

Zauważyć tu można ambiwalentny stosunek Kundery do przeszłości, która - podobnie jak los - oddziela się od jednostki i jej wpływu na rzeczywistość. Jest to pogląd zgoła odmienny od postulowanego w Czeskim losie zrozumienia dziejów i wagi momentu historycznego roku 1968 formacyjnego nie tylko dla Czechów, ale i wielu Europejczyków. Jednak nie tylko w przeszłości Kundera upatrywał wroga - silniejszym, jak się zdaje, niebezpieczeństwem był dla niego filtr z przyszłością, który określał ,najgorszym z konformizmów, tchórzliwym schlebianiem silniejszemu" (Kundera 2015b, s. 27).

Aby w pełni zobrazować tę (nie tylko) światopoglądową przemianę Kundery, powróćmy do postaci Taminy mierzącej się ze stratą: rodzinnego domu, kontaktów z najbliższymi i życia w ojczyźnie. Przyczyny powyższych strat spowodowane były zaostrzającą się stalinizacją, czyli wkroczeniem historii do życia bohaterki. Jednak niniejszy kontekst jest potrzebny Kunderze tylko do tego, by pokazać inną, dużo dotkliwszą stratę - śmierć męża Taminy i większości wspomnień z ich wspólnego życia. Los kobiety uznać można zatem za metaforę tytułowego zapomnienia, ale zapomnienia szczególnego - takiego, w którym następuje utrata nie tylko zakorzenienia, czyli ciągłości ze swoją przeszłością, ale zostaje zerwana również relacja z przyszłością, czyli horyzontem wszelkich możliwości. Wyspa dzieci, na której ostatecznie umiera Tamina, przypomina oniryczny obraz, gdzie oswobodzenie spod praw czasu i przestrzeni, wyzwala również z wyrzutów sumienia spowodowanych własnym zapomnieniem. Wyspa symbolizuje tak dotkliwą dziś archipelagizację kontaktów międzyludzkich, śmiech dzieci to z kolei zbliżanie się ludzkości do znienawidzonego przez autora stanu dziecięcości - dzieci nie oglądają się za siebie, zatem nie pozwalają, aby przyszłość ugięła się pod ciężarem pamięci (Kundera 2013, s. 260). Ta odarta z wszelkiego prawdopodobieństwa scena ukazuje dwa kluczowe przesłania Kundery: powieść jest polem do gry wyobraźni i stanowi alternatywę dla rzeczywistości uwikłanej w historię, w której można uwolnić się od tyranii pamiętania i bólu bycia osądzonym. I drugie: historia rozpatrywana z perspektywy przyszłości jest wrogiem człowieka, odziera go z prawa do niewiedzy, pomyłek i marzeń, jest również niebezpieczna dla projektowania zdrowych i potrzebnych utopii, bowiem

Człowiek jest kimś, kto posuwa się we mgle. [...] Nie widzieć mgły [...] to zapomnieć, czym jest człowiek, zapomnieć, czym sami jesteśmy (Kundera 2013, s. 260).

Stawka projektu powieściowego Kundery z lat siedemdziesiątych i osiemdziesiątych jest wysoka: jeśli powieść środkowoeuropejska nie może oderwać się od historii i jeśli jej twórcy definiują siebie za pomocą doświadczenia zbiorowego redagowanego codziennie na nowo przez gazety i polityków, to należy spróbować - choćby tylko za pomocą wyobraźni - przezwyciężyć ów impas wprowadzając na scenę bohaterów, dla których pamięć i zapomnienie mają twarz drugiego, konkretnego człowieka. Dopiero wówczas można wyzwolić się z myślenia opozycjami i znaleźć metafory na opisanie stanu bycia ,pomiędzy". 


\section{Teoria kozla ofiarnego, czyli Europa Środkowa jako laborato- rium zmierzchu}

W jednym z rewizjonistycznych tekstów poświęconych postkunderowskiej myśli środkowoeuropejskiej autorstwa George'a Schöpflina (2012) pojawia się teza, jakoby Kundera był zaskoczony (a wręcz zszokowany) ogromnym oddźwiękiem i sprawczością, które wywołał tekst Zachód porwany albo tragedia Europy Środkowej. Ten niewielki utwór po raz pierwszy opublikowany w 1983 roku we francuskim czasopiśmie „Le Débat” zrewolucjonizował narrację środkowoeuropejską na długie lata. Również dziś sięgając po najnowsze opracowania dotyczące tego problemu, żaden $\mathrm{z}$ badaczy nie decyduje się na pominięcie myśli Kundery. Jest to sytuacja prawdziwie paradoksalna, ponieważ już w latach osiemdziesiątych, tuż po przełożeniu tekstu na inne języki obce, pisarz zabronił jego przedruku i dalszych tłumaczeń. Najbardziej pożądany utwór środkowoeuropejski stał się jednocześnie tym najtrudniej dostępnym. Nie jest to zachowanie nietypowe dla Kundery i nie powinno ono zaskakiwać jego wiernych czytelników. Przypuszczenia jakoby pisarz nie przewidział skutków Zachodu porwanego wydają się być również chybione, biorąc pod uwagę dotychczasowy kontekst społeczno-polityczny jego powieści i reakcji na nie. Ale nie o sprawczość polityczną chodzi, bowiem w moim przekonaniu tekst Kundery był naturalnym, czy wręcz koniecznym następstwem ewolucji myśli samego pisarza, a jego zaskoczenie - jeśli istotnie się pojawiło - dotyczyło zapewnie nie tego, jak bardzo postawione w nim tezy rezonowały, ale jak niefortunnie zostały one zrozumiane.

Aby uświadomić sobie, o jaką stawkę w latach osiemdziesiątych toczyła się dyskusja $\mathrm{z}$ tekstem Kundery, na początku należy przywołać słownik pojęć, poniekąd już znanych ze wcześniejszych publikacji i wypowiedzi autora. Celowo nie nazywam Zachodu porwanego albo tragedii Europy Środkowej esejem, ponieważ w mojej opinii to gatunkowe przyporządkowanie wyraźnie zubożyło i zdeterminowało linię interpretacyjną tekstu. Dość przypomnieć, że partie eseistyczne są integralną częścią każdej powieści pisarza - wypowiadają je bohaterowie, narrator, czy sam odautorski głos. Poprzedzająca analizowany utwór Ksiega śmiechu i zapomnienia jest chyba najbardziej hybrydową powieścią Kundery, w której partie eseistyczne momentami przeważają nad akcją powieści. W tym kontekście niedostrzeganie w Kunderze-eseiście Kundery-powieściopisarza jest błędem prowadzącym do wielu interpretacyjnych pomyłek i rozczarowań. Słowem-kluczem w refleksji nad Zachodem porwanym zostaje ponownie los, tym razem jednak wyraźnie zrównany z pojęciem duchowym i kulturowym, pod którym ukrywa się zachodnioeuropejskie dziedzictwo. Kundera zastrzega jednak, że jego refleksja nie ma nic wspólnego z geografią, mimo że posługuje się pojęciem Europy Zachodniej, Wschodniej i Środkowej.

Po 1945 roku granica między dwiema Europami przesunęła się o kilkaset kilometrów na Zachód i narody, które dotąd uważały się za zachodnie, obudziwszy się pewnego poranka stwierdziły, że znajdują się na Wschodzie. [...] Geograficznie Europa Środkowa jest środkiem, kulturalnie - Zachodem, a politycznie - od 1945 roku Wschodem (Kundera 1984, s. 25).

To podstawowe i wielokrotnie przywoływane rozróżnienie jest swoistą mapą wyobrażoną drugiej połowy XX wieku, za pomocą której Kundera objaśnia kondycję państw środkowoeuropejskich (Węgier, Czech i Polski) jako „wyrzuconych z kolein własnego losu”, kiedy „tracą najgłębszą istotę swojej tożsamości” (Kundera 9184, s. 30). Następuje tu ponowne, dobrze już znane z Księgi śmiechu i zapomnienia, oddzielenie losu, tym razem jednak nie od jednostki, a od całych narodów. Po raz kolejny Kunderowski los zostaje zdeterminowany przez wizję nieuchronności historii, tym razem jednak pisarz wprowadza do swojego tekstu inną zmienną, a mianowicie wymiar kulturowy, który tak wyraźnie akcentował blisko dwadzieścia lat wcześniej w Czeskim losie. Europa, Zachód, kultura, ojczyzna i los stają się $\mathrm{w}$ utworze Kundery swoistymi synonimami. Zrównanie pojęć $\mathrm{z}$ tak różnych porządków ma w moim przekonaniu wyraźny potencjał afektywny $z$ jednej strony i fikcjonalny (w sensie powieściowym) $\mathrm{z}$ drugiej. Pisarz konstruuje pierwszego winowajcę - Rosję - używając do 
tego retoryki opartej na pejoratywnych skojarzeniach: jest ona zachłannym imperatorem, kulturowym monolitem niezdolnym do przeobrażeń, a jej ogromna przestrzeń jest odwrotnie proporcjonalna do ubogiej tradycji kulturowej. Kundera nie tylko orientalizuje Rosję, ale świadomie zrównuje ją z wielkim obcym, wrogiem i złym. To, co diametralnie różne (Rosja) w eseju Kundery, atakuje to, co znane i oswojone (Europę Środkową) - dezintegracja u pisarza polega na narzuceniu gwałtem rosyjskiego mroku, który z założenia jest dla Zachodu obcy:

Oto dlaczego Europa, która nazywam Środkową, odczuwa z a mi a ne s w o j e g o 1 o s u [podkr. - M.B.] po roku 1945 nie tylko jako katastrofę polityczną, lecz jako zakwestionowanie swej cywilizacji. Głęboką racją oporu krajów środkowoeuropejskich jest obrona ich tożsamości, albo inaczej - obrona ich zachodniości (Kundera 1984, s. 28)

Czy środkowoeuropejski los został zdeterminowany jedynie przez nadrzędnego wroga, czyli Rosję? Kundera odpowiada przecząco i do swojej opowieści wprowadza dobrze już znanego agensa, czyli Zachód, jednak pozbawia go immanentnego atrybutu, a mianowicie owej zachodniości właśnie. Zachód Europy w drugiej połowie XX wieku przestaje być Zachodem. To, co według Kundery stanowiło o europejskości, czyli religia w średniowieczu, a następnie kultura w oświeceniu już nigdy więcej nie będzie integrowało narodów zachodnioeuropejskich:

Zrozumieliśmy, że kultura jako dziedzina, w której realizują się najwyższe wartości, już nie istnieje. [...] W Europie Europa przestała być odczuwana jako wartość (Kundera 1984, s. 26).

Zatem drugim, zmetaforyzowanym wrogiem w tekście Kundery jest postęp, który zostawia w tyle kraje Europy Środkowej. Pisarz powraca tutaj do problemu celowego zapominania o istnieniu narodów leżących w sercu starego kontynentu. Narody te zostały wymazane z mapy Zachodu. Przyczyny takiego stanu rzeczy są co najmniej dwie: pierwsza, którą głębiej objaśnia Tony Judt (1990), związana jest z ignorancją powojennej polityki prezentowanej przez zachodnioeuropej- skich intelektualistów, dla których kraje Europy Środkowej kojarzone są jedynie ze Związkiem Radzieckim. Według historyka Zachód porzucił swoją celową amnezją dopiero wówczas, gdy kraje te zdecydowały się na rewizję marksizmu poprzez ruchy emancypacyjne (między innymi KOR czy Kartę 77). Powolna śmierć ideologii marksistowskiej w latach siedemdziesiątych i osiemdziesiatych XX wieku przyczyniła się do ponownego zauważenia Europy Środkowej. Podobnego zdania jest również Marci Shore, dla której „Miejsce marksizmu zajął dyskurs »Europy Środkowej«, praw człowieka i życia w prawdzie" (Shore 2012, s. 174). Druga przyczyna niewidzialności krajów Europy Środkowej związana jest ściśle z omawianym już „czeskim pytaniem”, które w Zachodzie porwanym Kundera stawia na nowo:

$Z$ jednej strony przyparte do muru przez Niemców, z drugiej - przez Rosjan, narody te wyczerpały zbyt wiele sił w walce o przeżycie i o własny język. Nie będąc w stanie przeniknąc wystarczająco głęboko do świadomości europejskiej, pozostały najmniej znaną i najbardziej kruchą częścią Zachodu (Kundera 1984, s. 27).

W powyższej analizie widać wyraźny wpływ myśli czeskiego filozofa Jana Patočki, który w swoich znanych esejach Kim sa Czesi? zabrał głos we wspomnianym już przeze mnie sporze o sens czeskich dziejów. Ten wybitny fenomenolog i dysydent zaproponował odważny, bo dychotomiczny (i dlatego pozwalający na dyskusje) podział na wielkie i małe dzieje Czech. Te pierwsze wiązały się z przekraczaniem horyzontu przetrwania i samozaspokojenia narodu na rzecz kultury opartej na uniwersalnych wartościach, które mogą stanowić wkład w całą wspólnotę europejską. Za takie uważał okres panowania Karola IV Luksemburskiego czy ruch reformatorski z tradycją husycką i Braćmi Czeskimi na czele. Owa siła ducha i intelektu skończyła się wraz z klęską czeskich protestantów na Białej Górze. Kultura wyzwolonych sług, czyli wiek XVIII, XIX i XX, nie miała czego zaproponować światu poza własnym nacjonalizmem językowym, oddolnym budowaniem suwerennego społeczeństwa i poddaniem się w kluczowej dla tego narodu chwili, czyli w Monachium roku 1938.

Kundera przejął od Patočki nie tyle skrajny krytycyzm, ile watpliwości, czy kraje środka w dłuższej perspektywie czasowej istotnie 
podołają roli odkupiciela. Wrogowie: Rosja - imperialna i komunistyczna oraz historia europejska, z którą narody środka są nierozerwalnie złączone stanowią awers i rewers dla tej samej, dominującej narracji. Czy zatem swoisty Kunderowski trójkąt można odczytywać tropem przemocy i niewinnej ofiary? Koncepcja kozła ofiarnego, którym zostały kraje Europy Środkowej, bardzo dobrze obrazuje mechanizmy zastosowane przez Kunderę w Zachodzie porwanym albo tragedii Europy Środkowej. René Girard opisał teorię kultury posługując się dwoma kluczowymi pojęciami: pragnienia mimetycznego i kozła ofiarnego (zob. Girard 1987). Pierwsze $z$ ich opiera się na naśladowaniu pragnienia Innego, co ostatecznie dowodzi, że człowiek nie jest istotą autonomiczną, a wszelka wspólnotowość oparta jest na mechanizmach zbiorowych. Z kolei tym, co charakteryzuje takie wspólnoty, jest rywalizacja o dobra (których pragnienie warunkowane jest mimetycznie) i przemoc, a te ostatecznie prowadzą do wskazania kozła ofiarnego. Wspólnota dręczona kryzysami wierzy, że za ich powstanie odpowiada konkretny podmiot, a dokonanie na nim rytualnego mordu pomaga przywrócić mechanizmy wspólnotowe, poczucie jedności i sprawczości:

Według Girarda ten mechanizm obwiniania niewinnego i uniewinniania siebie jest fundamentem każdej kultury ludzkiej i jednocześnie czymś w rodzaju wstydliwej tajemnicy, nieświadomego residuum, które nie może zostać ujawnione, ażeby wspólnota trwała w dobrostanie (Zawisza 2016)

W opowieści Kundery Europa Środkowa jest swoistym Innym, ale Innym rozpoznanym przez Zachód, choć ciągle odmiennym i niewygodnym, który samym swoim bytem przypomina o pewnym braku i zaniechaniu. Ten jeden podzielony organizm - zachodnio- i środkowoeuropejski - konstytuuje swoją tożsamość na amputacji organu, jakim jest Rosja, z całym jej komunistycznym szafarzem, któremu Kundera w latach pięćdziesiątych pomagał zadomowić się w Czechosłowacji. Jednocześnie bez owego organu kraje Europy Środkowej nie mogłyby pełnić roli ofiary-odkupiciela. Wyraźne odróżnienie się od wszystkiego, co rosyjskie, a zatem komunistyczne i zaakcentowanie własnej oryginalności i wyjątkowości jest w Zachodzie porwa- nym skrajnie przerysowane. W moim przekonaniu Kunderowska koncepcja Europy Środkowej jest koncepcją literacką, na którą składają się wyraźnie określeni bohaterowie, dramatyczne zwroty akcji, napięcie emocjonalne oscylujące między pragnieniem a nienawiścią oraz pewna ulga związana z podmiotowością Europy Środkowej jako kozła ofiarnego, który niejako przypieczętowuje status quo złej kondycji kulturowej Europy u zmierzchu XX wieku. Bo co bardziej wikła czytelnika emocjonalnie od zaangażowania się w powieść przygodową z tak spektakularnymi zwrotami akcji?

Tego rysu fabularnego w Zachodzie porwanym albo tragedii Europy Środkowej nie dostrzegło wielu odbiorców Kundery. Pierwsze polemiczne teksty ukazały się już w 1985 roku w emigracyjnym czasopiśmie „Svědectví”, a większość zarzutów wymierzanych w autora Żartu dotyczyło zafałszowywania Historii ${ }^{11}$. Milan Šimečka zwrócił uwagę, że w tekście pominięte zostały zbrodnie nazistowskich Niemiec i Hitlera - dziecka Europy Środkowej, na rzecz zdemonizowania skutków reżimu komunistycznego. Milan Hauner zarzucił Kunderze rasizm w stosunku do Rosjan i celowe przeoczenie tego, że na Imperium składa się rzesza małych narodów, których pisarz najwyraźniej broni tylko pozornie. Co więcej, to w Europie Środkowej dokonał się Oświęcim, deportacje milionów ludzi i inne zbrodnie wojenne. Przywołane tu głosy polemiczne stanowią przeciwwagę dla środkowoeuropejskiej wizji Kundery, ale - co trzeba dodać - nie sa one pozbawione uogólnień, skrajnych porównań, agresywnych ripost i obcego Kunderze założenia, że Niemcy należą do Europy Środkowej. Kulturowa koncepcja środkowoeuropejskości została w znacznej mierze sprowadzona do koncepcji politycznej i historycznej. Oponenci Kundery wyrażali żal, że Zachód porwany na długie lata zdeterminował refleksję nad Europą Środkową, w której przeważały emocje, a nie prawda historyczna. W ujęciu Kundery natomiast jedynym zwycięzcą jest zawsze prawda powieści.

${ }^{11}$ Zob. „Svědectví” 1985, nr 74. W tym numerze kwartalnika opublikowano polemiki autorstwa m. in. Milana Šimečki, Milana Haunera czy Jánosa Kisa. Polskie streszczenie tych głosów przywołał Andrzej Jagodziński w tekście Milan Kundera w polemikach (Jagodziński 2012, s. 21-29). 


\subsection{A co, jeśli powieść umrze? Umrze też Europa Środkowa}

Pisząc w Zachodzie porwanym o wyobrażonych granicach Europy Środkowej, Kundera wyraża potrzebę ich każdorazowego definiowania, w zależności od danej sytuacji i kontekstu. Jest to w gruncie rzeczy postulat wymyślania nowych pojęć i kategorii, które mogłyby wchodzić ze sobą w interakcje, tworzyć metafory i tym samym pomagać odnaleźć się w świecie targanym przez rozmaite racje historyczne. Jednak w tym samym czasie, kiedy na łamach „Svědectví” toczyła się polemika o sposób ujmowania Europy Środkowej, w czasopiśmie „Listy” ukazał się tekst Evy Kantůrkovej, która podała w wątpliwość zasadność nie tyle dyskusji, ile istnienia idei środkowoeuropejskości w ogóle (zob. Kantůrková 1985, s. 19-22). Według czeskiej badaczki, Milan Kundera znajduje się w wielkim błędzie, myśląc, że swoją anachroniczną nostalgią może wskrzesić świat, który już dawno przeminął. Nie pomogła mu w tym emigracja, gdzie pisarz jeszcze bardziej oddalił się od problemów i codzienności Czechów. Czy zatem ten nagły rozbłysk i kariera pojęcia Europy Środkowej w latach osiemdziesiątych był jednocześnie łabędzim śpiewem? Może walka między Wschodem i Zachodem, rozpatrywanie swojego losu w kategoriach zaczerpniętych z XIX-wiecznego odrodzenia narodowego i w końcu odpowiedzialność spoczywająca na roli kozła ofiarnego nie są metaforami na miarę końca XX wieku?

Upadek Cesarstwa, a po roku 1945 zepchnięcie Austrii na kulturowe pobocze oraz polityczne nieistnienie pozostałych państw czynią z Europy Środkowej zwierciadło odbijające możliwy los przyszłej Europy; czynią z niej laboratorium zmierzchu (Kundera 2015b, s. 147)

- w tak skonstruowanej definicji Europy Środkowej Kundera wydaje się być świadomym zmiany paradygmatu, która nieubłaganie czeka kraje środka.

Istnieje jednak wyraźny związek między Europą Środkową a sztuką powieści, nie dość wyraźnie podkreślany przez komentatorów twórczości Kundery. Wszystkie przywołane już przeze mnie metafory składające się na leksykon Środkowoeuropejczyka są tak naprawdę apologią tego, od czego zaczęłam pisanie niniejszego tekstu - powieści. W opinii autora Nieznośnej lekkości bytu to właśnie pisarze z Europy Środkowej: Musil, Broch, Kafka, Gombrowicz szczególnie zainteresowali się kondycją podmiotu, który nie rozumie rzeczywistości i porusza się we mgle na oczach innych ludzi-obserwatorów. Skąd taka wrażliwość wśród pisarzy Europy Środkowej? Kundera dostrzega tutaj rodzaj pewnego napięcia wynikającego z poczucia schyłkowości: zaniknięcia imperium austro-węgierskiego, a później tragedii drugiej wojny. Temat odchodzenia i zmierzchu pisarz wprowadza do każdej swojej powieści, zaznaczając jednocześnie, że człowiek, który utracił łączność z samym sobą, ze swoimi bliskimi oraz coraz bardziej oddaloną od niego rzeczywistością nie jest świadomy życia w epoce zmierzchu:

[...] błogi uśmiech, z jakim wygłasza się nekrologii powieści wydaje mi się nadto frywolny. Frywolny, ponieważ ja widziałem już i przeżyłem śmierć powieści, jej gwałtowną śmierć (zadawaną przy użyciu zakazów, cenzury ideologicznych nacisków) w świecie, w którym spędziłem większą część życia, a nazywanym zazwyczaj totalitarnym. Okazało się w nim dobitnie że powieść jest czymśs śmiertelnie kruchym, równie nietrwałym co Zachód Czasów Nowożytnych (Kundera 2015b, s. 21).

Cenzura i polityczne działania zniewalania sztuki przez reżim totalitarny to jedna z przyczyn śmierci powieści. Drugą przyczyną jest nowoczesny egoizm i zarozumiałość cechujące świat zachodni, który Kundera poznawał na emigracji. Oba te tematy pojawią się w fabule Księgi śmiechu i zapomnienia, kiedy pisarz podejmuje problem grafomanii, a ta z kolei w epoce schyłkowej oznaczać będzie izolowanie się od drugiego człowieka ${ }^{12}$. W tym celu Kundera przegląda się w powie-

12 „Powszechna samotność wywołuje grafomanię, ale jednocześnie powszechna grafomania utwierdza i powiększa ogólną samotność. Wynalazek druku umożliwił niegdyś ludzkości wzajemne porozumiewanie się. W czasach powszechnej grafomanii pisanie książek uzyska odwrotny sens: każdy jest otoczony swymi literami jak ścianą z luster, przez którą nie dochodzi żaden głos z zewnątrz" (Kundera 2013, s. 131-132).

Dziś niemal w identyczny sposób można zdefiniować bańki informacyjne, które tworzą już nie tyle pisarze, ile media i ich odbiorcy. 
ściowym krzywym zwierciadle i prezentuje postać Banaki - pisarzagrafomana symbolizującego upadek sztuki powieściopisarstwa.

Kiedy Banaka powiada, że sztuka powieści przebrzmiała, gdyż złudzeniem jest zrozumienie drugiego człowieka, wyraża nie tylko modną postawę estetyczną, lecz, o czym nie wie, nędzę swą własną i całego swego otoczenia: brak chęci zrozumienia drugiego; egocentryczna ślepote na świat rzeczywisty (Kundera 2013, s. 229).

Zachód zobaczył własną śmierć w Europie Środkowej. Europa Środkowa natomiast zobaczyła własną śmierć w odchodzeniu powieści. Kundera w gruncie rzeczy wytrwale pyta: a co, jeśli powieść umrze? Umrze też Europa Środkowa, potem umrze Zachód rozumiany jako wspólnota europejska. A z każdą z tych śmierci zostanie osamotniony człowiek, który nie znajdzie słów na opisanie własnej kondycji w świecie. Ten łańcuch przyczynowo-skutkowy znaleźć można we wszystkich tekstach Milana Kundery, aż w końcu staje się niemal idée fixe samego autora. Zatem pytając o pojęcie Europy Środkowej, pisarz nie pyta jedynie o tyranię historii, która zawłaszcza narracje i pamięć, totalizuje kulturę i dominuje nad wyobraźnią; pyta również o kondycję człowieka w świecie, który potrafi wziąć w nawias zdeterminowany i obcy los. Wówczas znajduje miejsce na pracę wyobraźni, na próbę pomyślenia nieprawdopodobnego, które łączy pojęcie losu, fatum, a nawet mitu. Postawienie tych wszystkich pojęć, metafor i koncepcji obok siebie uświadamia ich cechy wspólne, niewidzialne połączenia, emocjonalne kontaminacje.

\section{Appendix do kondycji Środkowoeuropejczyka}

Przewidziany przez Kunderę schyłek powieściowego czyli kulturowego paradygmatu przybrał formę trzech nieobojętnych w swej wymowie wydarzeń. Na początku października 2008 roku w czeskim tygodniku „Respekt” ukazał się tekst Petra Třešňáka i Adama Hradilka o tytule Donos Milana Kundery [Udáni Milana Kundery] (Třešňák, Hradilek 2020). Był to utrzymany w tonie sensacji reportaż informujący, że czternastego kwietnia 1950 roku Milan Kundera zawiadomił milicję o tym, że na terenie praskiego akademika, w pokoju stu- dentki Ivy Militki zatrzymał się Miroslav Dvořáček - kadet, uciekinier z Czechosłowacji do amerykańskiej strefy okupacyjnej w Niemczech, tajny pracownik Czechosłowackiej Agencji Wywiadowczej. „Respekt” wydrukował fragment kopii złożonego przez Kunderę donosu na człowieka, którego nigdy nie znał. O jego wizycie w akademiku dowiedział się od kolegi - partnera Ivy Militki. Dvořáček cudem uniknął kary śmierci, spędził czternaście lat $w$ więzieniach $i$ obozach pracy. Artykuł powstał na podstawie badań młodego historyka Hradilka, który prowadził kwerende badawczą w praskim Instytucie Badań nad Reżimami Totalitarnymi i zupełnie przypadkiem natknął się na tę sprawę. Kopie odkrytych dokumentów wysłał mieszkającemu w Szwecji Dvořáčkowi, dopiero wówczas były więzień poznał nazwisko donosiciela. Martin Šimečka, znany słowacki pisarz i syn wspomnianego już oponenta Kundery, Milana Šimečki, był w tym czasie redaktorem naczelnym „Respektu” - zdecydował o ujawnieniu tajemnicy archiwów, argumentując, że Czesi potrzebują prawdy będącej swoistym katharsis. W ujęciu Šimečki tak pojęta prawda jest nie tylko kolejnym krokiem na drodze do dekomunizacji kraju, ale przede wszystkim umożliwia stawianie nowych pytań: czy Kundera-moralizator, autor tekstów o wolności, m.in. Czeskiego losu czy Zachodu porwanego miał prawo kreować i na długie lata zdeterminować debatę publiczną, a swoją twórczością tak mocno wpłynać na wyobraźnię czytelników (zob. M. Šimečka 2020)? Sam Milan Kundera wszystkie doniesienia uznał za kłamstwo i nigdy nie przyznał się do winy. Za jedyny komentarz pisarza uznać można jego powieści - to w nich, zwłaszcza w Żarcie i w Życie jest gdzie indziej redaktor naczelny „Respektu" odnalazłby odpowiedzi na swoje pytania.

Podobną poradę można udzielić Janowi Novákowi, który w 2020 roku wydał niezwykle kontrowerysjną i liczaca niemal dziewięćset stron biografię Kundery. Jest to tekst niewolny od resentymentu i miejscami przypominający najgorszy tabloid. Ponownie w centrum analizy znalazły się sprawy osobiste (żyjącego ciągle) pisarza oraz jego uwikłanie w politykę. Twórczość Kundery zajęła poślednie miejsce w zainteresowaniach biografa. Uporczywe milczenie autora Nieznoś- 
nej lekkości bytu zdaje się jedynie pobudzać publiczną debatę, która o kulturze ma do powiedzenia coraz mniej. Pisarz sam zresztą taki scenariusz przewidział - właśnie tak rozumianej przyszłości, która zamienia się w osądzający trybunał, obawiał się najbardziej.

Natomiast dziesiątego września 2020 roku ukazał się ostatni numer pisma „Le Débat”, w którym Kundera opublikował swój manifest środkowoeuropejski. Po czterdziestu latach działalności twórcy pisma uznali, że nie da się już dłużej prowadzić debaty publicznej opartej na wspólnych wartościach. W XXI wieku zjawisko archipelagizacji stało się tak powszechne i dotkliwe, że wymiana myśli między poszczególnymi wsypami jest niemożliwa - wyspy nie mają granicy, przez które komunikacja mogłaby przepływać.

Co zatem pozostało z dziedzictwa Europy Środkowej - kozła ofiarnego Zachodu i Wschodu, bez którego żadna ze stron nie mogłaby istnieć? Dlaczego wiara w konstytutywną rolę kultury, która podtrzymuje ideę dialogiczności, przybiera formę nasilających się narracji nacjonalistycznych i ksenofobicznych? Jak przeprowadzić dziś pracę mądrego pamiętania i mądrego zapominania? Wartości i umiejętności, w które chciał wierzyć Kundera oblekają się dzisiaj w szaty nie tyle swoich przeciwieństw, ile drastycznych skrajności. A tę powolną transformację Europy Środkowej pisarz doskonale przewidział.

\section{Literatura}

D o n s k is L., 2012, I Remember, therefore I Am: Milan Kundera and the Idea of Central Europe [in:] Yet another Europe after 1984. Rethinking Milan Kundera and the idea of Central Europe, ed. L. Donskis, Amsterdam: Brill, Rodopi.

IV. Sjezd Svazu československých spisovatelů, 1968a, Praha: Československý spisovatel.

Gir a rd R., 1987, Kozioł ofiarny, tłum. M. Goszczyńska, Łódź: Wydawnictwo Łódzkie, wydanie elektroniczne.

H a v e 1 V., 1969, Český los? Online: https://is.muni.cz/el/1423/jaro2011/SOC403/ um/Cesky_udel.pdf [dostęp: 25.09.2020].

H a v e 1 V., 2011, Sita bezsilnych, thum. A. Holland, [w:] idem, Sita bezsilnych i inne eseje, wyb. A. S. Jagodziński, Warszawa: Agora.

J a g o d zi ń s ki A., Milan Kundera w polemikach, [w:] Kundera. Materiały z sympozjum zorganizowanego $w$ Katowicach $w$ dniach 25-26 kwietnia $1986 r$. red. J. Illg, Londyn 1988, s. 21-29.
J u d t T., 1990, The Rediscovery of Central Europe, „Dedalus”, nr 119, ss. $23-54$.

J u d t T., S n y d e r T., 2019, Rozważania o wieku XX, thum. P. Marczewski, Poznań Rebis.

K a n t ů r k o v á E., 1985, Dějina, dějiny, dějinnost, „Listy”, nr 5, ss. 19-22.

K o 1 a A. F., 2011, Europa w dyskursie polskim, czeskim i chorwackim. Rekonfiguracje krytyczne, Torun: Wydawnictwo Naukowe Uniwersytetu Mikołaja Kopernika.

Ku ndera M., 1968, Český úděl? Online: https://is.muni.cz/el/1423/jaro2011/ SOC403/um/Cesky_udel.pdf [dostęp: 25.09.2020].

K u nd e r a M., 1969, Radikalismus a exhibicionismus. Online: https://is.muni.cz/el /1423/jaro2011/SOC403/um/Cesky_udel.pdf [dostęp: 25.09.2020].

K u n d e r a M., 1984, Zachód porwany albo tragedia Europy Środkowej, „Zeszyty Literackie", nr 5

K u n d e r a M., 1993, Three Contexts of Art: From Nation to World, „Cross Currents", vol. 12, s. 5-14.

Kundera M., 2013, Księga śmiechu i zapomnienia, thum. A. S. Jagodziński, P. Godlewski, Warszawa: W.A.B.

Kundera M., 2015a, Zdradzone testamenty, thum. M. Bieńczyk, Warszawa: W.A.B.

K u n d e r a M., 2016b, Sztuka powieści, thum. M. Bieńczyk, Warszawa: W.A.B.

Kundera. Materiaty z sympozjum zorganizowanego $w$ Katowicach $w$ dniach 25-26 kwietnia 1986 r., red. J. Illg, Londyn 1988.

M a s a ry k T. G., 1969, Česká otázka. Snahy a tužby národního obrození, Praha: Melantrich.

S c h a u e r H. G., 1917, Spisy, Praga: Kamilla Neumannová.

S chöpfli in G., 2012, Central Europe: Kundera, Incompleteness, and Lack of Agency, [in:] Yet Another Europe After 1984: Rethinking Milan Kundera and the Idea of Central Europe, red. L. Donskins, Amsterdam: Brill, Rodopi.

S hor e M., 2012a, Nowoczesność jako źródto cierpień, thum. M. Sutowski, Warszawa: Wydawnictwo Krytyki Politycznej.

S h o r e M., 2012b, Smak popiołów. Odziedzictwie totalitaryzmu w Europie Wschodniej, tłum. M. Szuster, Warszawa: Świat Książki.

„Svědectví” 1985, nr 74. Online: http://scriptum.cz/cs/periodika/svedectvi [dostęp: 08.10.2020]

Š i me čk a M., 2008, The Owner of the Key, „Respekt”. Online: https://www. respekt.cz/respekt-in-english/the-owner-of-the-key [dostęp: 10.11.2020].

Tř e šňá k P., H r a di 1 e k A., 2008, Udání Milana Kundery. Online: https://www. respekt.cz/tydenik/2008/42/udani-milana-kundery [dostęp: 10.11.2020].

$\mathrm{Z}$ a w is z a R.,2016, Bez końca $z$ Girardem $i$ tak aż do końca świata... Online: https://www.miesiecznik.znak.com.pl/bez-konca-z-girardem-i-tak-az-dokonca-swiata [dostęp: 10.10.2020]. 